\title{
Quaternary palaeoceanography and palaeogeography in northern Denmark: a review of results from the Skagen cores
}

\author{
KAREN LUISE KNUDSEN, KELD CONRADSEN, SUSANNE HEIER-NIELSEN \\ \& MARIT-SOLVEIG SEIDENKRANTZ
}

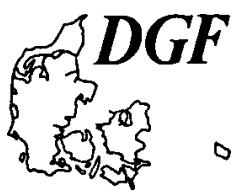

Knudsen, K. L., Conradsen, K., Heier-Nielsen, S. \& Seidenkrantz, M.-S.:
Quater-nary palaeoceanography and palaeogeography in northem Denmark: a
review of results from the Skagen cores. Bulletin of the Geological Society of
Denmark, Vol. 43. pp. 22-31. Copenhagen, 1996-07-14.
https://doi.org/10.37570/bgsd-1996-43-03

Palaeoenvironmental reconstructions from the Skagen record contribute to the understanding of Late Quatemary climatic changes and variations in the oceano-graphic circulation pattem in the entire North Atlantic region. The Skagen cores penetrated c. $192 \mathrm{~m}$ of Quatemary sediments comprising two marine Late Quater-nary records: A $7 \mathrm{~m}$ marine unit (185.3-178.3 m) comprised the entire last inter-glacial, including its lower and upper transitions (Late Saalian-Eemian-Early Weichselian), while the upper $132 \mathrm{~m}$ of marine deposits covered the last about 15,000 years from the Late Weichselian through the Holocene, including the Pleistocene-Holocene transition. Results from the study of lithology, foraminifera, stable isotope measurements and radiocarbon dates are reviewed while emphasiz-ing the most important contributions to the general understanding of the North Atlantic Quatemary history.

Karen Luise Knudsen, Keld Conradsen, Susanne Heier-Nielsen \& Marit-Solveig Seidenkrantz, Department of Earth Sciences, University of Aarhus, DK-8000 Arhus C, Denmark. S. Heier-Nielsen also at AMS ${ }^{14} \mathrm{C}$ Dating Laboratory, Institute of Physics and Astronomy, University of Aarhus, DK-8000 Århus C, Denmark. December 1st, 1995.

\section{Introduction}

The North Atlantic current system plays an important role in the understanding of both global and regional climatic systems of the past (e.g. Lehman \& Keigwin 1992; Bond et al. 1993; Weaver \& Hughes 1994). As changes in northwest European climate and oceanography are strongly influenced by variations in the influx of Atlantic water into the Norwegian Sea and the North Sea, the NW European shelf areas appear to be key areas in the understanding of these fluctuations.

The present surface current system in the North Atlantic (Fig. 1) has probably been the prevailing oceanographic setting, not only through the Holocene, but also through at least a major part of each of the previous interglacial periods. During glacial periods, however, the Polar Front was displaced to an area off southem Europe, while the North Atlantic Current was considerably weakened, perhaps even completely 'shut down' during certain periods (e.g. Weaver \& Hughes 1994; Bond 1995). These migrations of the water masses are also clearly reflected in the Danish shelf sediments.
During the Late Quatemary an up to about $300 \mathrm{~m}$ deep palaeo-embayment, the Kattegat Depression, stretched from the Skagerrak across northem Jutland and into the Kattegat sea (Fig. 2) (see the base Quaternary map in Lykke-Andersen 1987 and Lykke-Andersen et al. 1993a). This embayment was connected to the North Sea and the North Atlantic to the northwest and may be considered to have been a palaeoextension of the Norwegian Trench. The palaeoembayment has gradually been filled with sediments from the Late Saalian through to the Holocene.

This scenario resulted in the deposition of thick marine sedimentary sequences, which enable highresolution studies of the palaeoenvironment of the late Quatemary. Previous studies of the foraminifera from the Kattegat Depression have mainly focused on the Eemian and Early Weichselian (Bahnson et al. 1974; Knudsen \& Lykke-Andersen 1982; Lykke-Andersen, A.-L. 1987; Knudsen 1992; Seidenkrantz 1993a, 1993b) and the Late Weichselian (Feyling-Hanssen et al. 1971; Knudsen 1978; Knudsen \& Nordberg 1987; Bergsten \& Nordberg 1993; Seidenkrantz \& Knudsen 1993). In addition, Holocene deposits from the Kattegat and Skagerrak regions have previously been studied, 
Fig. 1. Location of sites mentioned in the text and the present surface current system in the North Atlantic.

NAD = North Atlantic Drift; E. CH. = English Channel.

The area covered by Figure 2 is indicated.

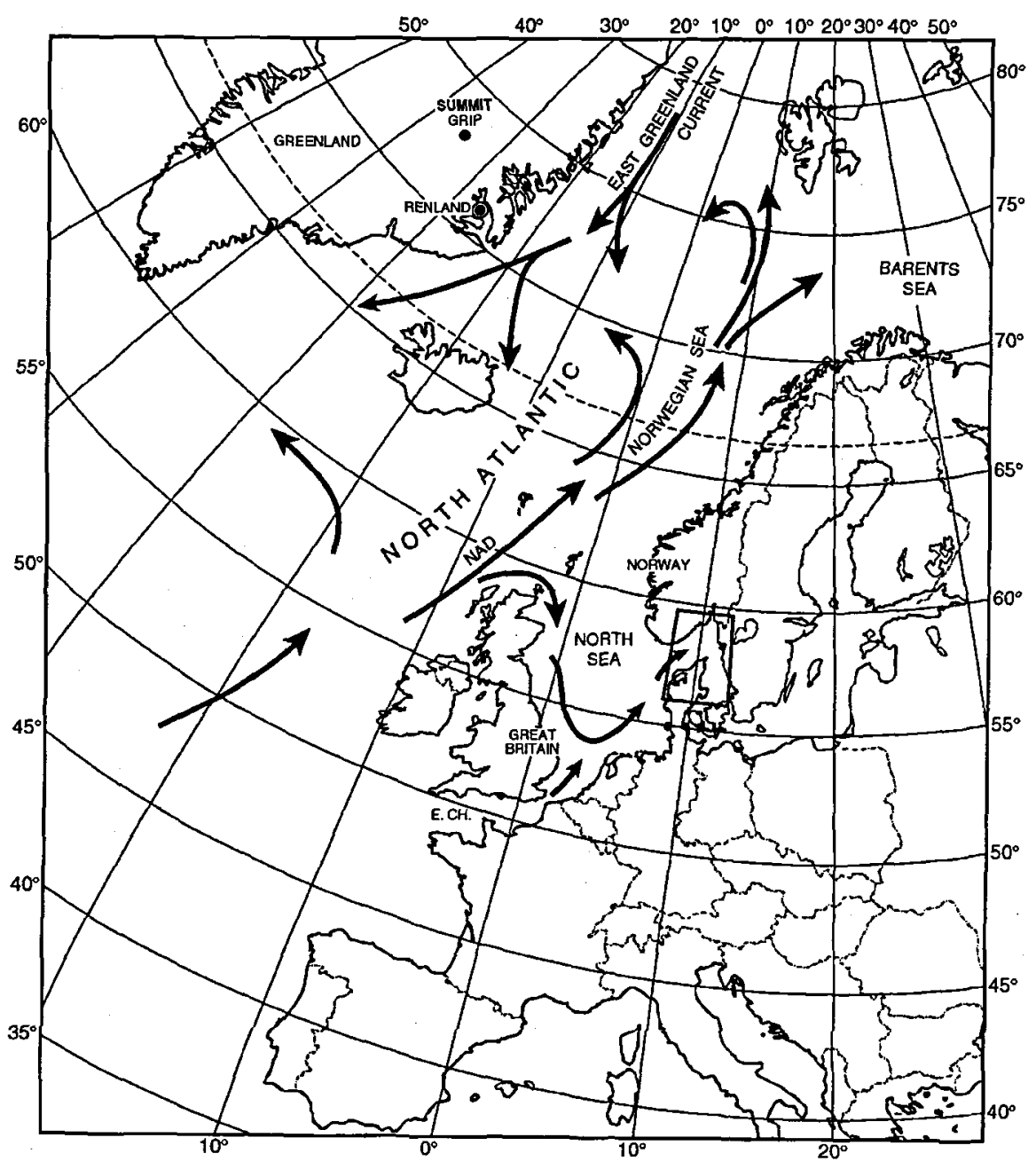

e.g. Fält (1982), Nordberg \& Bergsten (1988), Nordberg (1989) and Conradsen (1995). It has, however, hitherto not been possible to compare the boundary conditions of both the Eemian and the Holocene at the same site.

The purpose of this paper is to present a review of the Quaternary stratigraphy of the Skagen 3 and Skagen 4 cores (Figs 2-3) based on lithology, foraminiferal analyses, stable isotope results and AMS radiocarbon dates. In addition, we have placed emphasis on a comparison of the Eemian and Holocene records as well as the glacial-interglacial transitions at this specific site.

A short compilation of ongoing work including some preliminary results from the Skagen cores is given by Knudsen (1994). More detailed studies of the foraminiferal and stable isotope stratigraphy from the glacial-interglacial-glacial cycle at Skagen are presented by Seidenkrantz et al. (1995) and Seidenkrantz \& Knudsen (unpublished). Results of foraminiferal analyses, stable isotope results and ${ }^{14} \mathrm{C}$ dates from the Late
Weichselian and Holocene sequence, including the Pleistocene-Holocene transition, are given by Knudsen et al. (1996), Conradsen \& Heier-Nielsen (1995) and Heier-Nielsen et al. (1995), while geotechnical properties from the boreholes are discussed by Thorsen (1995a, 1995b) and Thorsen \& Mortensen (1995).

Further palaeoenvironmental studies of the Skagen record are in progress at a number of different institutions, these being the Geological Survey of Denmark and Greenland (sediments and molluscs), University of Lund (diatoms), University College London (ostracods), University of Cambridge (pollen) and Université de Québec à Montréal (dinoflagellates). The chronology of the record beyond the range of the ${ }^{14} \mathrm{C}$ dating method is being determined at the Bergen Amino acid Laboratory and at the Luminiscence Laboratory at Risø (preliminary results in Poolton et al. in press). 


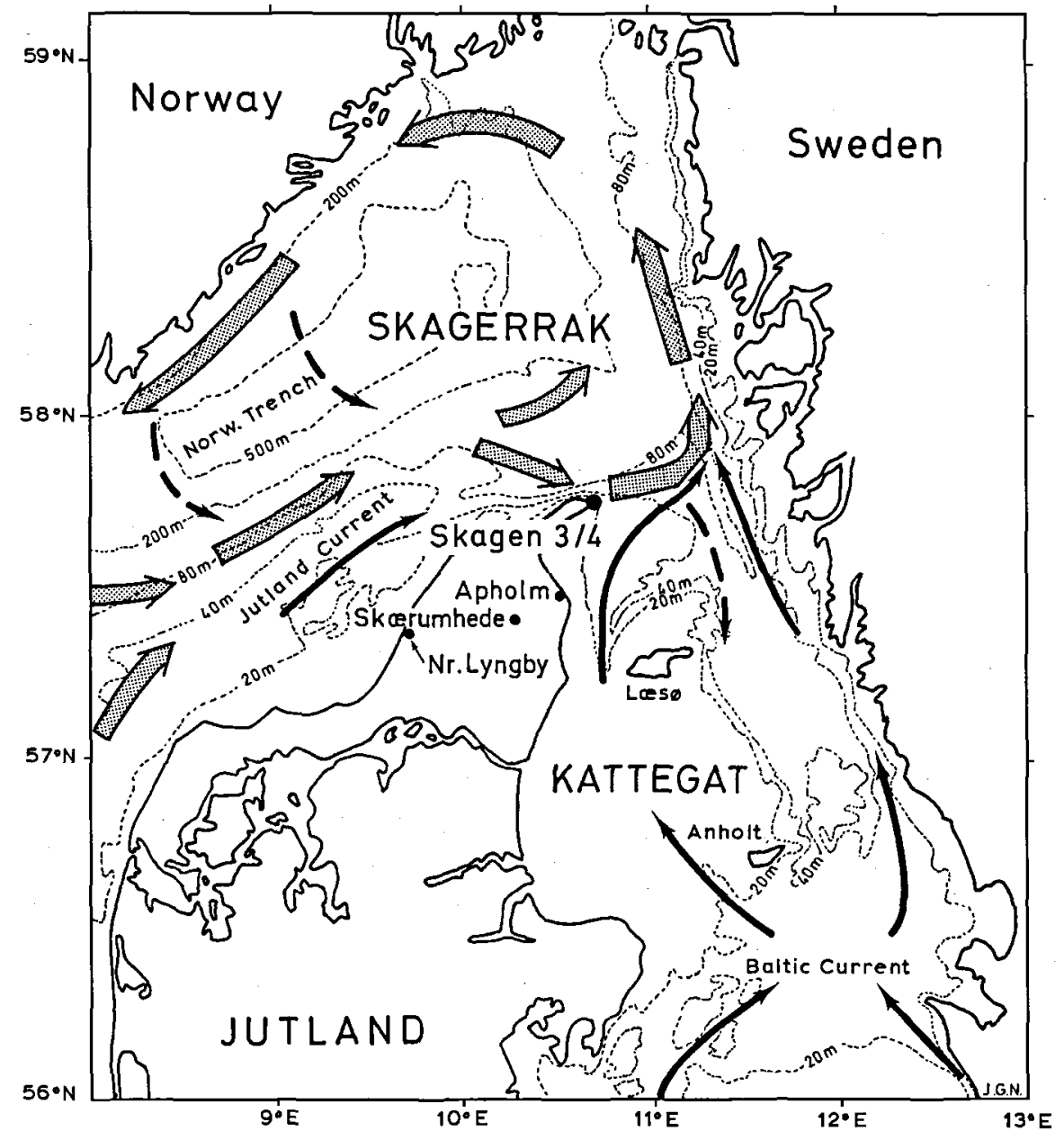

Fig. 2. Present regional oceanographic circulation pattern and location of sites

mentioned in the text. Redrawn from Svansson (1975) and Nordberg (1991).

\section{The Skagen 3 and Skagen 4 boreholes}

The borings were carried out in 1992 and 1993 just north of the city of Skagen (Fig. 2) at $1 \mathrm{~m}$ above sea level. Two oil exploration wells had previously been drilled in the area, but the new borings are the first to provide material of the standard required to enable a detailed study of the Quaternary strata. Skagen 3 covers the interval between 30 and $220 \mathrm{~m}$ depth while Skagen 4 supplements with the uppermost $30 \mathrm{~m}$. The Skagen 3 core reached the pre-Quaternary (Lower Cretaceous non-marine sands) at c. $192 \mathrm{~m}$ depth (see Knudsen 1994).

The drilling and laboratory techniques have been described by Conradsen \& Heier-Nielsen (1995), Knudsen et al. (1996) and Seidenkrantz \& Knudsen (unpublished).
The Saalian-Eemian-Early Weichselian cycle (192-178.3 m)

The oldest Quaternary deposits at Skagen represent non-marine glacigenic sands, clays and diamicts (Fig. 3 ), corresponding to the Saalian Glacial (oxygen isotope stage 6) (see also Knudsen 1994).

A marine transgression subsequently occurred in the Late Saalian, and marine clays with subarctic benthic foraminferal faunas dominated by Elphidium excavatum (Terquem) forma clavata Cushman and Cassidulina reniforme Nørvang were deposited (Zone M, Figs 4-5).

The Saalian/Eemian transition (stage 6/5e) is marked by the gradual immigration of warm water species; first Bulimina aculeata d'Orbigny and $B$. marginata d'Orbigny (grouped as B. marginata in Figs 4-5) together with Cassidulina laevigata d'Orbigny (Zone L) and later, in addition, Melonis barleeanus (Williamson), Bolivina skagerrakensis (Qvale \& Nigam) and 


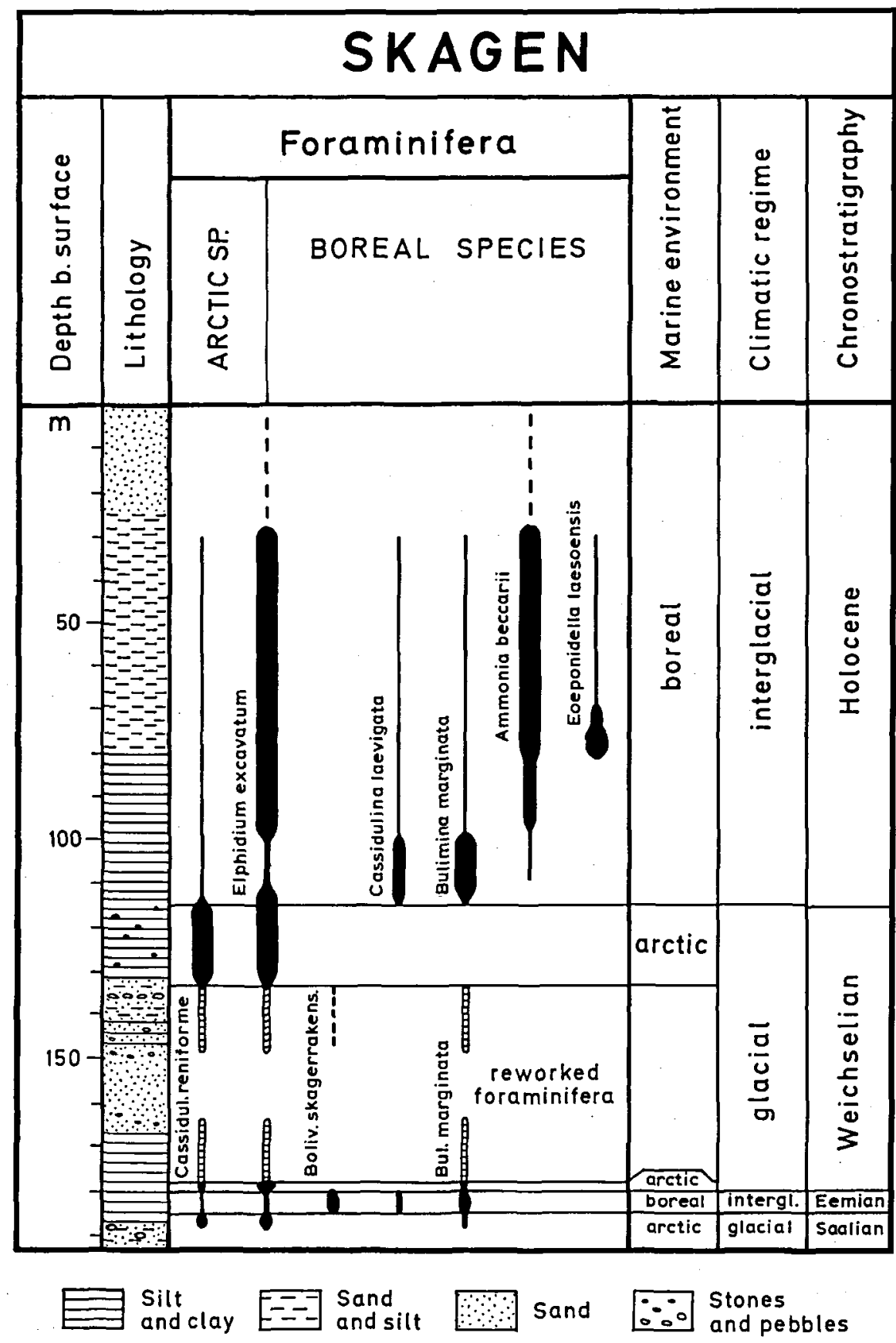

Fig. 3. Simplified range chart for the Quaternary in the Skagen 3 and 4 cores showing the relative distribution of a few selected foraminiferal species. The foraminiferal species are separated into two groups; those with arctic and those with boreal environmental preference. Elphidium excavatum occurs both in arctic waters (as forma clavata) and in boreallusitanian waters (as forma selseyensis). Reworked, or partly reworked, foraminifera are indicated by horizontal hatching on the diagram. Lithology is based on discriptions by Ole Bjørslev Nielsen (personal communication 1993) (see also Knudsen 1994). 


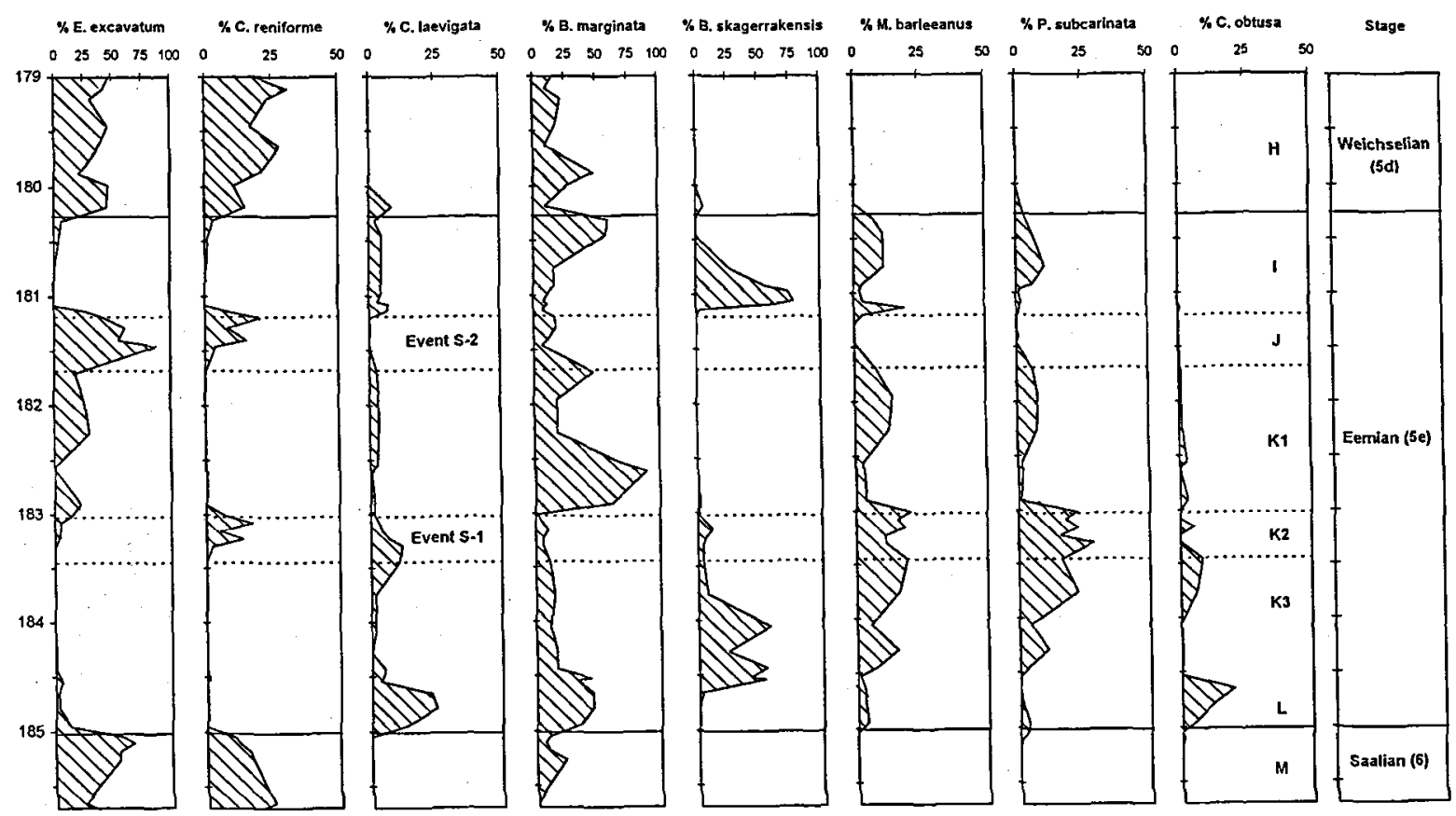

Fig. 4. Percentages of selected foraminiferal species in the glacial-interglacial-glacial cycle (Saalian-Eemian-Early Weichselian). The interval between 185.7 and $179.0 \mathrm{~m}$ depth in the Skagen 3 core is shown. The two mid-Eemian cooling events (Event S-1 and S-2), the foraminiferal zonation (Zones $\mathbf{M}$ to $\mathrm{H}$ ) and the chronostratigraphy are indicated in the diagram. Further details in Seidenkrantz et al. (1995) and Seidenkrantz \& Knudsen (unpublished).

Pullenia subcarinata (d'Orbigny) (Zone K3, Figs 4 5). These species are among the characteristic warm water elements in the main part of the $5 \mathrm{~m}$ thick Eemian Interglacial deposits (Zones L-I).

In two intervals within the Eemian, however, the foraminiferal assemblages differ from the remaining Eemian strata. The lower interval (Event S-1, Subzone $\mathrm{K} 2$ ), is marked by a peak in the arctic species $C$. reniforme in an otherwise temperate fauna, and the upper interval (Event $S-2$, Zone J) is characterized by the truly subarctic fauna of $C$. reniforme and $E$. excavatum (Fig. 4). The two cooler intervals also show excursions in stable isotope values (Seidenkrantz \& Knudsen, unpublished).

These two periods of cooling are presumably the most remarkable features of the Eemian Interglacial record in the Skagen 3 core (further discussed by Seidenkrantz et al. 1995 and Seidenkrantz \& Knudsen unpublished). Marine Eemian sediments from the region have been well documented for many years, e.g. from Skærumhede, Apholm, Nørre Lyngby and Anholt (Fig. 2) (Knudsen \& Lykke-Andersen 1982; Knudsen 1984; Lykke-Andersen, A.-L. 1987; Seidenkrantz 1993a, 1993b), but similar coolings have not previously been recorded in the interglacial record. We presume that this is due to lack of recovery from the relevant levels in these older cores.

The Eemian sediments at Skagen are succeeded by $2 \mathrm{~m}$ of marine clays with a subarctic foraminferal fauna dominated by E. excavatum, C. reniforme, Epistominella takayanagii Iwasa, $B$. marginata and $B$. aculeata. This interval is allocated to part of the Early Weichselian (substage 5d, Seidenkrantz et al. 1995; Seidenkrantz \& Knudsen unpublished). A more complete Lower Weichselian sequence has previously been recorded at Apholm (Knudsen 1984, 1992), but insufficient sample resolution has prevented a detailed study of the record. A study of climatic oscillations in an Early Weichselian marine record at Nørre Lyngby is, however, in progress (Kristensen et al., unpublished).

\section{The Early to Middle Weichselian} (178.3-132 m)

About $45 \mathrm{~m}$ of clays and sands with scattered pebbles and stones superpose the marine Lower Weichselian at Skagen. It contains a relatively badly preserved benthic foraminiferal assemblage. The fauna is dominated by a mixture of arctic species (E. excavatum, $C$. reniforme, Islandiella helenae Feyling-Hanssen \& Buzas, Haynesina orbiculare (Brady) and Elphidium bartletti Cushman) and warm water species (e.g. $B$. skagerrakensis, $B$. marginata and $C$. laevigata), suggesting that a significant number of the specimens have been reworked. The warm water species were possibly transported into an arctic, glaciomarine environ- 
ment with an existing fauna. A similar $30-40 \mathrm{~m}$ thick basin fill containing mixed, partly mixed or perhaps fully reworked foraminiferal assemblages have previously been identified in several borings in the region, i.e. Skærumhede, Læs $\varnothing$ and Anholt (Fig. 2) (Bahnson et al. 1974; Knudsen 1986; Seidenkrantz 1993b), and this sequence can also be followed on seismic profiles over most of the Kattegat Depression (Lykke-Andersen et al. 1993b).

The Main Weichselian Glaciation is presumed to be indicated by a marked concentration of pebbles and stones in the uppermost part of this basin fill sediment (c. 137-135 m depth; Fig. 3).

\section{The Late Weichselian and the Holocene (132-0 m)}

A marine environment was re-established in the area at about 15,000-14,500 BP (from $132 \mathrm{~m}$ depth in the core). The sedimentation rate was high, and the marine clays initially contain a scatter of ice-rafted stones and foraminiferal assemblages dominated by ice-proximal species such as $E$. excavatum f. clavata and $C$. reniforme (Zone F; Figs 3 and 6 ).

The sedimentation rates decreased markedly between about 13,100 and 9,600 BP (between 117 and $114 \mathrm{~m}$ depth), and there was a temporary maximum of accessory species such as Nonionellina labradorica (Dawson) (see Fig. 6 and Knudsen et al. 1996), Astrononion gallowayi Loeblich \& Tappan and Cibicides lobatulus (Walker \& Jacob) in the assemblages. In addition, two other accessory species, Stainforthia loeblichi (Feyling-Hanssen) and Pullenia osloensis Feyling-Hanssen, appeared in the lower and upper part of this interval (see Knudsen et al. 1996).

The fluctuations in the foraminiferal faunas within this period, associated with fluctuations in stable isotope values (Fig. 6), show that the climatic variations of the Bølling Interstadial, the Older Dryas Stadial, the Allerød Interstadial, the Younger Dryas Stadial and the Preboreal affected the oceanographic conditions in the Kattegat-Skagerrak area (see also Knudsen et al. 1996). The bottom waters were still influenced by cold, normal saline Atlantic water masses imported through the Norwegian Trench, presumably as a compensation current to an increased outflow of meltwater from the Baltic area during the Bølling-Allerød Interstadial complex and the Preboreal. Minor changes during the Older Dryas and Younger Dryas Stadial periods in both the foraminiferal fauna and the isotopic composition indicate short periods when there was reduced stratification of the water column. Reduced meltwater outflow seems to have resulted in enhanced mixing of the water.

Thus, arctic/subarctic conditions prevailed in the deep Skagerrak during the entire Bølling-Allerød Interstadial complex, the Younger Dryas and the early part of the Preboreal. Previous studies (e.g. Knudsen
1978; Bergsten \& Nordberg 1992; Conradsen 1995) have shown, however, that during the same period of time warmer foraminiferal assemblages occurred at least periodically in shallower water environments in the Skagerrak-Kattegat region.

Only minor changes occurred in the foraminiferal assemblages at the Pleistocene-Holocene transition (Subzone E3/E2 boundary; $115 \mathrm{~m}$ depth). The first boreal species, C. laevigata, had already appeared by Subzone E2 and increased through Subzone E1 together with $P$. osloensis, while $C$. reniforme and $N$. labradorica decreased (Fig. 6). In general, however, arctic/subarctic environments still prevailed in the area until about 9,600 BP.

After 9,600 BP (i.e. during the remaining part of the Preboreal and during the Boreal period; Zones $D$ and C; Fig. 6) there was a consistent occurrence of $C$. laevigata and a pronounced increase in other boreal species such as $B$. marginata concurrent with a decrease in both $E$. excavatum and $C$. reniforme. This indicates increased bottom temperatures, reflecting a major inflow of warm Atlantic water masses into this relatively deep area of the eastern North Sea basin. Thus, full-interglacial hydrographic conditions were first established in the entire region after 9,600 BP. A similar two-stage post-Younger Dryas oceanographic transition with a first change prior to $10,000 \mathrm{BP}$ and a second a few hundred years later has been previously recorded in the Skagerrak, the Norwegian Sea and the North Atlantic (e.g. Bergsten 1994; Koç Karpuz \& Jansen 1992; Lehman \& Keigwin 1992; Sarnthein et al. 1994).

At about 7,600 $\mathrm{BP}$ a distinct change occurred in the Holocene fauna (at $100 \mathrm{~m}$ depth in core). B. marginata and $C$. laevigata declined markedly (Fig. 3 ) and $E$. excavatum forma selseyensis (Heron-Allen \& Earland) and Ammonia beccarii (Hofker) became the most significant species. This type of fauna is identical to that found in recent assemblages around Skagen (Conradsen et al. 1994), indicating the establishment of the modern circulation pattern in the North Sea and Skagerrak-Kattegat areas after opening of the English Channel (e.g. Jelgersma 1979; Lehman et al. 1991; Nordberg 1991) and the Danish Straits (e.g. Winn et al. 1986; Björck 1995). After 7,600 BP the sedimentary conditions were significantly influenced by sediment transport in the Jutland Current (including the coastal current), which caused the development of the Skagen Spit. The Holocene development of the Skagen Spit is shown in Figure 7.

A faunal change and a lithological change at about $5,500 \mathrm{BP}$ (c. $81 \mathrm{~m}$ depth in core; Fig 3 ) is indicated by the immigration of a new species (Eoeponidella laesoeensis Michelsen) into the area and lithologically by the deposition of relatively coarser sediments (see also Conradsen \& Heier-Nielsen 1995). The change to higher energy conditions probably reflects a more pronounced Jutland Current and thus increased inflow of North Sea water into the Kattegat (see also e.g. Nord- 

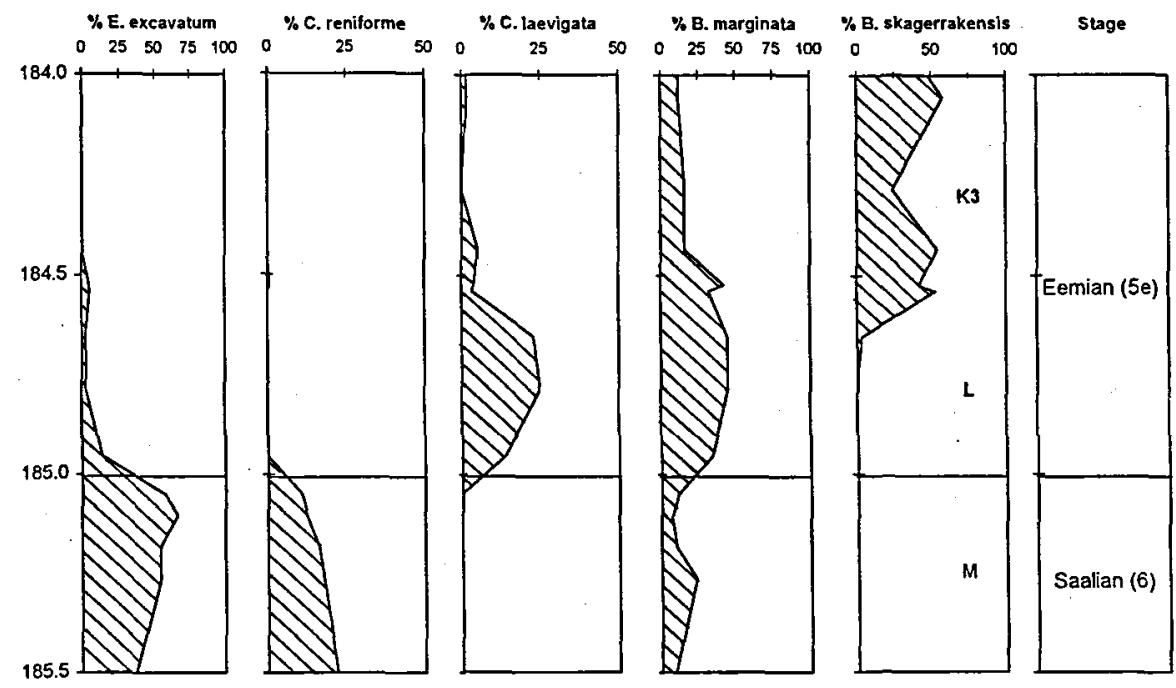

Fig. 5. Details of the distribution of selected species at the glacialinterglacial transition from the Late Saalian to the Early Eemian at around $185 \mathrm{~m}$ depth in the Skagen 3 core. Foraminiferal assemblage zones (Zones $\mathrm{M}$ to $\mathrm{K} 3$ ) and chronostratigraphy are indicated (see Seidenkrantz et al. 1995 and Seidenkrantz \& Knudsen, unpublished).

berg 1991). This modification of the hydrographic system in the Skagerrak-Kattegat region is most likely a response to the climatic cooling at the end of the Holocene climatic optimum in Atlantic time and may thus reflect a regional cooling of the surface water masses of the North Atlantic.

\section{Comparison of the Eemian and Holocene Interglacials}

During the last interglacial (Eemian) the temperatures were generally a few degrees higher than those experienced during the Holocene and today in the North Atlantic region (e.g. Sejrup \& Larsen 1991; Knudsen 1992; Larsen et al. 1995; Johnsen et al. 1995a). This is also confirmed by our data from Skagen (Seidenkrantz $\&$ Knudsen, unpublished). In contrast to the relatively stable temperature conditions during the Holocene, studies of the GRIP ice core from the Summit of the Greenland ice cap suggest that the Eemian Interglacial comprised significant climatic fluctuations (e.g. Dansgaard et al. 1993; GRIP Members 1993; Larsen et al. 1995; Johnsen et al. 1995b). Similar climatic variations have also been documented both in the terrestrial environment in NW Europe (e.g. Tzedakis et al. 1994; Thouveny et al. 1994), in marine deposits in the North Atlantic (e.g. Seidenkrantz \& Rahman, unpublished; Fronval et al., unpublished; Sejrup et al. in press), and in NW European shelf deposits, as demonstrated by Seidenkrantz et al. (1995), Seidenkrantz \& Knudsen (unpublished) and in the present paper. The two mid-Eemian cool periods may have been caused by a temporary weakening of the North Atlantic Drift (Seidenkrantz et al. 1995). In this context, a discussion of the climatic influence of east-west oscillations of the oceanic front systems between Polar and Atlantic surface waters in the Norwegian Sea was recently presented by Sejrup et al. (in press).

In European terrestrial records, the Eemian climatic optimum seems to have occurred within the first 3000 years of the interglacial, and a similar early climatic optimum for this period has been demonstrated in the Norwegian Sea (see Larsen et al. 1995). This corresponds to the longest period with temperatures higher than at present in the GRIP ice core. A comparable early Holocene climatic optimum is known from the North Atlantic region, including the Renland ice core from East Greenland (e.g. Iversen 1973; Nesje \& Kvamme 1991; Johnsen \& Dansgaard 1992) and has recently also been demonstrated in the GRIP ice core from Greenland (Johnsen et al. 1995a). It has not been possible to identify a climatic optimum in the initial part of the Eemian record at Skagen in the present study.

Larsen et al. (1995) calculated that a transgression maximum occurred about 2000 years later than the Eemian climatic optimum. This has not been detectable in the Skagen record either. The general palaeowater depth at the site was presumably too great (200$300 \mathrm{~m}$ ) to detect any minor fluctuations in sea level through the interglacial period (Seidenkrantz \& Knudsen, unpublished).

Climatic oscillations, as reflected in both the foraminiferal assemblages and the stable isotope compositions of the Eemian record, are not found in the Holocene record from Skagen. The faunal succession in the Holocene sequence does, however, demonstrate changes in the hydrographic circulation pattern at about $7,600 \mathrm{BP}$ and at 5,500 BP. It is suggested that the earlier change was related to the opening of the English Channel and the Danish Straits, while the latter may reflect the general cooling in the North Atlantic region at end of the Holocene climatic optimum. The 


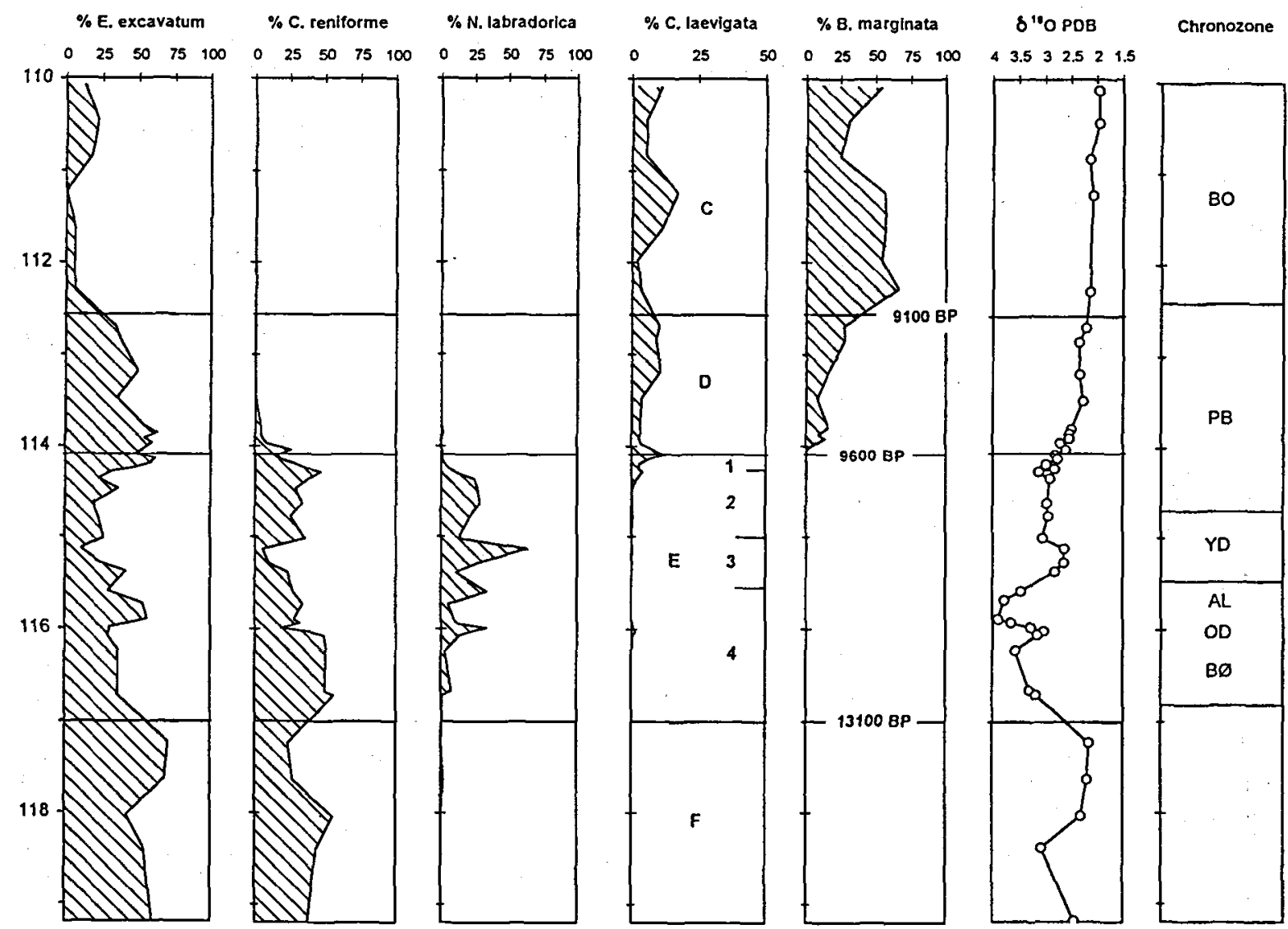

Fig. 6. Percentage distribution of selected foraminiferal species and the oxygen isotope values at the glacial-interglacial transition from the Late Weichselian to Early Holocene between 119 and $110 \mathrm{~m}$ depth in the Skagen 3 core. Foraminiferal assemblage zones (Zones $\mathrm{F}$ to $\mathrm{C}$ ) and the age of some important zone boundaries are indicated in addition to the chronostratigraphy (further details concerning the age model, see Knudsen et al. 1996). B $\emptyset=$ B $\emptyset$ lling; OD = Older Dryas; $\mathrm{AL}=$ Allerød; $\mathrm{YD}=$ Younger Dryas; $\mathrm{PB}=$ Preboreal; $\mathrm{BO}=$ Boreal.

changes in palaeo-water depth through the Holocene at Skagen were affected by both isostasy and global sea level, but the gradual decrease in water depth since about $9,000 \mathrm{BP}$ is largely attributed to the extremely high sediment accumulation rates in the area (Conradsen \& Heier-Nielsen 1995).

\section{The glacial-interglacial transitions}

Studies of the Late Saalian-Eemian transition in different parts of the world show that the overall gradual warming was interrupted by a short-term climatic deterioration comparable with the Younger Dryas cold spell at the Late Weichselian-Holocene transition (Seidenkrantz et al, in press). In the Danish area this has been demonstrated by the foraminiferal and stable isotope data from the Anholt core (Seidenkrantz 1993a). A similar complete record of the Late Saalian was not found at Skagen, even though the transition from the glacial into the interglacial is present in the sequence.

In general, the faunal change at the Saalian-Eemian transition in the Skagen core (Fig. 5) is very similar to that found at the Weichselian-Holocene transition (Fig. 6 ). The arctic species $E$. excavatum forma clavata and $C$. reniforme decrease markedly in frequency, while the boreal $C$. laevigata and $B$. marginata increase during the warming. In the Eemian sequence this faunal change is succeeded by immigration of a number of deep water species, e.g.B. skagerrakensis, which never migrated into the area at Skagen in the Holocene because the water depth in area was too shallow at that time (Conradsen \& Heier-Nielsen 1995; Conradsen et al. 1994).

The faunal changes at glacial-interglacial transitions, thus, generally seem to be much alike from one interglacial to another if the environmental conditions are comparable. Minor details in the assemblages may, 


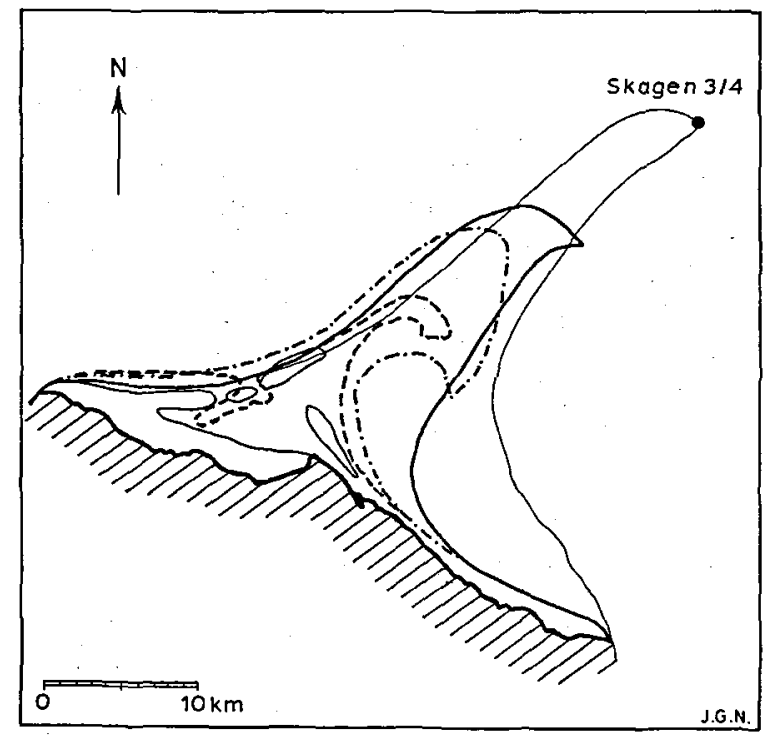

Coastlines
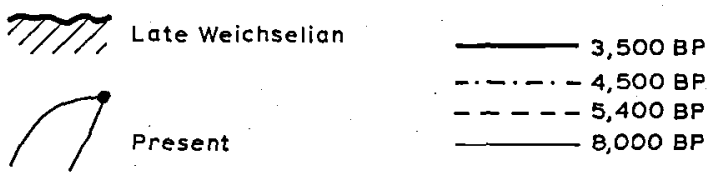

Fig. 7. Development of the Skagen Spit after about 8,000 BP. Redrawn from Hauerbach (1992).

however, prove to be important in the separation of different glacial-interglacial transitions in a particular area. Thus, the immigration of Cassidulina obtusa Williamson in the initial part of the Eemian Interglacial, as seen in the Skagen record (Fig. 4), might prove to be indicative of the Eemian in the region. A similar peak in C. obtusa is also seen at the Saalian-Eemian transition in the Apholm, the Anholt and the Nørre Lyngby cores (Knudsen 1984; Seidenkrantz 1993a; Kristensen et al., unpublished). Details in the immigration patterns at glacial-interglacial transitions are, however, not yet fully understood.

\section{Summary of results from the Skagen cores}

The high-resolution studies of the marine Quaternary sequences at Skagen contribute to the understanding of the Late Quaternary climatic and oceanographic history of the entire North Atlantic region. A summary of some of the most important observations and conclusions resulting from the study of lithology, foraminifera, stable isotopes and radiocarbon dates includes:

- Climatic oscillations in the Eemian Interglacial shelf record comparable to those described from the GRIP ice core in Greenland and in the terrestrial record of NW Europe. These oscillations are suggested to be associated with fluctuations in the North Atlantic Drift.

- A period in which glaciomarine ice-proximal conditions prevailed in the area between about 15,000 and 13,100 BP.

- The inflow of cold, normal saline Atlantic water masses at the bottom of the Skagerrak-Kattegat region during the Bølling-Allerød, the Younger Dryas and the early part of the Preboreal (c. 13,100-9,600 $\mathrm{BP})$, while higher temperature conditions prevailed in shallower areas during most of this time period. Indications of decreased stratification of the water column during the Older and the Younger Dryas cold events.

- Indication of the inflow of warm Atlantic water masses in the entire region at about 9,600 BP.

- The establishment of the present hydrographic circulation system in the North Sea and the SkagerrakKattegat area at approximately 7,600 BP. This is suggested to be associated with the opening of the English Channel and the Danish Straits.

- Modification of the current system at approximately $5,500 \mathrm{BP}$, which may be a result of the general cooling in the North Atlantic at the end of the Holocene climatic optimum.

- The bottom water temperatures at Skagen were generally a few degrees higher during the Eemian Interglacial than during the Holocene and at present.

- A general similarity in the faunal change at the Saalian-Eemian and the Weichselian-Holocene transitions, but with specific characteristics in the immigration pattern which might show to be important for age determinations.

\section{Acknowledgements}

The drilling at Skagen was part of a joint venture between the GeoKat project and the Skagen Spit Project and was financed by the Danish Natural Science Research Council and the Municipality of Skagen. Additional funding for the study was provided by the Carlsberg Foundation, Denmark and by the European Union SHELF-project. Our sincere thanks to Peter Kristensen for help with the laboratory work and for valuable discussions of the results, to Gillian Scott for correcting the English and to Jette Gissel Nielsen for help with the diagrams.

\section{Dansk sammendrag}

Palæomiljø-undersøgelser på grundlag af lithologi, foraminiferer, stabile isotoper og ${ }^{14} \mathrm{C}$ dateringer fra Skagen har vist sig at bidrage væsentligt til forståelsen 
af ændringer i klima og strømsystemer i hele det nordatlantiske område.

Skagen ligger i den centrale del af en dyb sydøstnordvest orienteret bassinstruktur i den præ-Kvartære overflade. Denne sydøstlige udløber af Norske Rende blev transgrederet af havet i Sen Saale og har siden været præget af periodevist meget høje sedimentationshastigheder i et marint miljø. De tykke marine lagserier i området giver grundlag for at foretage palæomiljø-undersøgelser med høj tidsopløsning.

Den Kvartære lagserie ved Skagen er ca. 192 m tyk og indeholder to bemærkelsesværdige marine enheder. I den dybere del af boringen (185,3-178,3 m) forekommer en $7 \mathrm{~m}$ tyk marin ler, som overlejrer glacigene sedimenter. Denne marine lagserie reprasenterer en hel glacial-interglacial-glacial cyklus fra Sen Saale, Eem og Tidlig Weichsel. Som det allerede er velkendt fra området, viser foraminiferfaunaerne, at temperaturen generelt var højere i Eem end på noget tidspunkt i Holocæn i det samme område. Derudover viser faunaerne og målinger af stabile isotoper, at det generelt varme klima har været afbrudt af to kuldeperioder. Disse klimatiske svingninger svarer til de, der er beskrevet fra GRIP iskernen på Grønland, og som fornylig også er registreret $i$ terrestriske aflejringer i NV Europa og i dybhavssedimenter i Nordatlanten. Svingningerne skyldes formodentlig variationer i styrke og eventuelt $i$ retning af Den nordatlantiske Strøm (Golfstrømmen).

Aflejringerne fra 178,3-132 m ved Skagen består af ler, sand og grus med et foraminiferselskab bestående af både arktiske og boreale arter. Dette sediment formodes at være afsat under Weichsel Istiden som en bassinudfyldning i denne sydlige udløber af Norske Rende. Lignende sedimenter med blandingsfaunaer, der er præget af store mængder af omlejrede foraminiferer, er også fundet $\mathrm{i}$ boringer ved Skærumhede, på Læsø og på Anholt.

De $\emptyset$ verste $132 \mathrm{~m}$ repræsenterer en marin aflejringsperiode, som dækker Sen Weichsel og hele Holocæn (indtil området blev land for ca. 300 år siden). Foraminiferer og stabile isotoper viser, at der herskede isproximale forhold i området mellem ca. $15.000 \mathrm{og}$ 13.100 BP. I Bølling-Allerød, Yngre Dryas og begyndelsen af Præboreal (13.100-9.600 BP) indikerer den bentoniske fauna relativt koldt, normal salint nordatlantisk vand. Disse atlantiske vandmasser formodes at være strømmet ind langs bunden af Norske Rende som en kompensationsstrøm til udstrømmende smeltevand fra det baltiske område. Svingninger i faunaerne i løbet af perioden tolkes som resultat af, at en reduceret udstrømning af smeltevand $i$ kuldeperioder delvist har opløst stratifikationen af vandsøjlen (ÆEldre Dryas og Yngre Dryas). Mens de dybere dele af Skagerrak-Kattegat var præget af koldt bundvand helt frem til tidlig Præboreal tid, var lavtvandsområderne periodevist karakteriseret af mildere faunaer allerede fra Bølling Interstadial tid. Først fra omkring $9.600 \mathrm{BP}$ var hele området præget af varme atlantiske vandmasser, og der herskede fuldt interglaciale forhold overalt.

Endringer i foraminiferfaunaerne ved Skagen viser, at det nuværende strømsystem i Nordsøen og Skagerrak-Kattegat området må være blevet etableret ca. 7.600 BP. Dette kobles sammen med åbningen af Den engelske Kanal og de danske balter. Den videre faunaudvikling og ændringen i lithologi tyder desuden på en mindre modifikation af cirkulationssystemet omkring 5.500 BP, hvilket sandsynligvis er et resultat af den generelle afkøling i Nordatlanten ved slutningen af det Holocæne klimatiske optimum.

\section{References}

Bahnson, H., Petersen, K. S., Konradi, P. B. \& Knudsen, K. L. 1974: Stratigraphy of Quaternary deposits in the Skærumhede II boring: lithology, molluses and foraminifera. Danmarks Geologiske Undersøgelse, Årbog 1973, 27-62.

Bergsten, H. 1994: A high resolution record of Lateglacial and early Holocene sediments from southwestern Sweden; with special emphasis on environmental changes close to the Pleistocene-Holocene transition and the influence of fresh water from the Baltic basin. Journal of Quaternary Science 9, 1-12.

Bergsten, H. \& Nordberg, K. 1992: Late Weichselian marine stratigraphy of the southern Kattegat, Scandinavia: evidence for drainage of the Baltic Ice Lake between 12,700 and 10,300 years BP. Boreas $21,223-252$.

Bergsten, H. \& Nordberg, K. 1993: Middle Weichselian marine sediments from eastern Kattegat, Scandinavia. Boreas 22, 311-318.

Björck, S. 1995: A review of the history of the Baltic Sea, 13.0-8.0 ka BP. Quaternary International 27, 19-40.

Bond, G. 1995. Climate and the conveyor. Nature 377, 383384.

Bond, G., Broecker, W., Johnsen, S., McManus, J., Labeyrie, L., Jouzel, J. \& Bonani, G. 1993: Correlation between climate records from North Atlantic sediments and Greenland ice. Nature 365, 143-147.

Conradsen, K. 1995: Late Younger Dryas to Holocene palaeoenvironments of the southern Kattegat, Scandinavia. The Holocene 5 (4), 447-456.

Conradsen, K., Bergsten, H., Knudsen, K. L., Nordberg, K. \& Seidenkrantz, M.-S. 1994: Recent benthic foraminiferal distribution in the Kattegat and the Skagerrak, Scandinavia. Cushman Foundation for Foraminiferal Research, Special Publication 32, 53-68.

Conradsen, K. \& Heier-Nielsen, S. 1995: Holocene paleoceanography and paleoenvironments of the SkagerrakKattegat, Scandinavia. Paleoceanography 10, 801-813.

Dansgaard, W., Johnsen, S. J., Clausen, H. B., Dahl-Jensen, D., Gundestrup, N. S., Hammer, C. U., Hvidbjerg, C. S., Steffensen, J. P., Sveinsbjörnsdóttir, A. E., Jouzel, J. \& Bond, G. 1993: Evidence for general instability of past climate from a 250 -kyr ice-core record. Nature 364, 218 220.

Feyling-Hanssen, R. W., Jørgensen, J. A., Knudsen, K. L. \& Lykke-Andersen, A.-L. 1971: Late Quaternary Foraminifera from Vendsyssel, Denmark and Sandnes, Nor- 
way. Bulletin of the Geological Society of Denmark 21, 67-317.

Fält, L.-M. 1982: Late Quaternary sea-floor deposits off the Swedish west coast. Department of Geology, Chalmers University of Technology and University of Göteborg A37, 259 pp.

GRIP Members 1993: Climate instability during the last interglacial period recorded in the GRIP ice core. Nature 364, 203-207.

Hauerbach, P. 1992: Skagen Odde - Skaw Spit - An area of land created between two seas. In Folia Geographica Danica Tom XX. C.A. Reitzels Forlag, Copenhagen, 119 pp.

Heier-Nielsen, S., Conradsen, K., Heinemeier, J., Knudsen, K. L., Nielsen, H. L., Rud, N. \& Sveinbjörnsdóttir, A. E. 1995: Radiocarbon dating of shells and foraminifera from the Skagen core, Denmark: Evidence of reworking. Radiocarbon 37, 119-130.

Iversen, J. 1973: The Development of Denmark's Nature since the Last Glacial. Geological Survey of Denmark. V Series 7-C, 1-126.

Jelgersma, S. 1979: Sea-level changes in the North Sea basin. In Oele, E., Schüttenhelm, R. T. E. \& Wiggers, A. J. (eds) The Quaternary History of the North Sea. Acta Universitatis Upsaliensis: Symposium Universitatis Upsaliensis Annum Quingentesimum Celebrantis 2, Uppsala, 233-248.

Johnsen, S. J., Clausen, H. B., Dansgaard, W., Gundestrup, N. S., Hammer, C. U. \& Tauber, H. 1995b: The Eem Stable Isotope Record along the GRIP Ice Core and Its Interpretation. Quaternary Research 43, 117-124.

Johnsen, S. J., Dahl-Jensen, D., Dansgaard, W. \& Gundestrup, N. S. 1995a: Greenland palaeotemperatures derived from GRIP bore hole temperature and isotope profiles. Tellus 47 B, 624-629.

Johnsen, S. J. \& Dansgaard, W. 1992; On flow model dating of stable isotope records from Greenland ice cores. In Bard, E. (ed) Proceedings of NATO Workshop: The Last Deglaciation, Absolute and Radiocarbon Chronologies. Erice, Italy, 1991, NATO ASI Series 12, 13-24.

Knudsen, K. L. 1978: Middle and Late Weichselian marine deposits at Nørre Lyngby, northern Jutland, Denmark, and their foraminiferal faunas. Geological Survey of Denmark. II Series 112, 1-59.

Knudsen, K. L. 1984: Foraminiferal stratigraphy in a marine Eemian-Weichselian sequence at Apholm, North Jutland. Bulletin of the Geological Society of Denmark 32, 169-180.

Knudsen, K. L. 1986: Foraminifer-stratigrafisk unders $\varnothing g e l s e$ af marint Weichsel på Læsø. In Bahnson, H., Knudsen, K. L. \& Hansen, J. M.: Læs $\varnothing$ 's Geologi. Lithologi, Biostratigrafi og Geofysik. Danmarks Geologiske Undersøgelse D6, 29-46.

Knudsen, K. L. 1992: A long marine Eemian-Weichselian shelf record in North Denmark, Scandinavia. In Kukla, G. J. \& Went, E. (eds) Start of a Glacial. NATO ASI Series I 3. Springer-Verlag Berlin Heidelberg, 157-171.

Knudsen, K. L. 1994: The marine Quaternary of Denmark: a review of new evidence from glacial-interglacial studies. Bulletin of the Geological Society of Denmark 41, 203-218.

Knudsen, K. L., Conradsen, K., Heier-Nielsen, S. \& Seidenkrantz, M.-S. 1996: Palaeoenvironments in the SkagerrakKattegat basin in the eastern North Sea during the last deglaciation. Boreas 25 (2), in press.
Knudsen, K. L. \& Lykke-Andersen, A.-L. 1982: Foraminifera in the Late Saalian, Eemian, Early and Middle Weichselian of the Skærumhede I boring. Bulletin of the Geological Society of Denmark 30, 97-109.

Knudsen, K. L. \& Nordberg, K. 1987: Late Weichselian and Holocene biostratigraphy in borings southeast of Frederikshavn, Denmark. Bulletin of the Geological Society of Denmark 36, 289-303.

Koç Karpuz, N. \& Jansen, E. 1992: A high resolution diatom record of the last deglaciation from the SE Norwegian Sea: documentation of rapid climatic changes. Paleoceanography 7, 499-520.

Larsen, E., Sejrup, H. P., Johnsen S. \& Knudsen, K. L. 1995: Do Greenland Ice Cores Reflect NW European Interglacial Climate Variations? Quaternary Research 43, 125132.

Lehman, S. J., Jones, G. A., Keigwin, L. D., Andersen, E. S., Butenko, G. \& Østmo, S.-R. 1991: Initiation of the Fennoscandian ice-sheet retreat during the last glaciation. Nature 349, 513-516.

Lehman, S. J. \& Keigwin, L. D. 1992: Sudden changes in North Atlantic circulation during the last glaciation. Nature 356, 757-762.

Lykke-Andersen, A.-L. 1987: A Late Saalian, Eemian and Weichselian marine sequence at Nørre Lyngby, Vendsyssel, Denmark. Boreas 16, 345-357.

Lykke-Andersen, H. 1987: Thickness of the Quaternary deposits and their relation to the pre-Quaternary in the Fennoscandian border zone in Kattegat and Vendsyssel. Boreas 16, 369-371.

Lykke-Andersen, H., Knudsen, K. L. \& Christiansen, C. 1993a: The Quaternary of the Kattegat area, Scandinavia: a review. Boreas 22, 269-281.

Lykke-Andersen, H., Seidenkrantz, M.-S. \& Knudsen, K. L. 1993b: Quaternary sequences and their relations to the pre-Quaternary in the vicinity of Anholt, Kattegat, Scandinavia. Boreas 22, 291-298.

Nesje, A. \& Kvamme, M. 1991: Holocene glacier and climate variations in western Norway: Evidence for early Holocene glacier demise and multiple Neoglacial events. Geology 19, 610-612.

Nordberg, K, 1989: Sea-floor deposits, paleoecology and paleohydrography in the Kattegat during the later part of the Holocene. Department of Geology, Chalmers University of Technology and University of Göteborg A65, 205 pp.

Nordberg, K. 1991: Oceanography in the Kattegat and Skagerrak over the past 8000 years. Paleoceanography $6,461-$ 484.

Nordberg, K. \& Bergsten, H. 1988: Biostratigraphic and sedimentological evidence for hydrographic changes in the Kattegat during the later part of the Holocene. Marine Geology 83, 135-158.

Poolton, N. R. J., Bøtter-Jensen, L., Wintle, A. G., Ypma, P. J., Knudsen, K. L., Mejdahl, V., Mauz, B., Christiansen, H. E., Jacobsen, J., Jørgensen, F. \& Willumsen, F. in press: A scanning system for measuring the age-related luminiscence of split sediment cores. Boreas.

Sarnthein, M., Winn, K., Jung, S. J. A., Duplessy, J.-C., Labeyrie, L., Erlenkeuser, H. \& Ganssen, G. 1994: Changes in east Atlantic deepwater circulation over the last 30,000 years: Eight time slice reconstructions. Paleoceanography $9,209-267$.

Seidenkrantz, M.-S. 1993a: Benthic foraminiferal and stable isotope evidence for a "Younger Dryas-style" cold 
spell at the Saalian-Eemian transition, Denmark. Palaeogeography, Palaeoclimatology, Palaeoecology 102, 103120.

Seidenkrantz, M.-S. 1993b: Foraminifera from the Quaternary in the Anholt boring, Denmark. Boreas 22, 283-291.

Seidenkrantz, M.-S., Bornmalm, L., Johnsen, S. J., Knudsen, K. L., Kuijpers, A., Lauritzen, S.-E., Leroy, A. G., Mergeai, I., Schweger, C. \& Vliet-Lanoë, B. van in press: Twostep deglaciation at the oxygen isotope stage 6/5e transition: the Zeifen-Kattegat climate oscillation. Quaternary Science Reviews.

Seidenkrantz, M.-S. \& Knudsen, K. L. 1993: Middle Weichselian to Holocene palaeoecology in the Eastern Kattegat, Scandinavia: foraminifera, ostracods and ${ }^{14} \mathrm{C}$ measurements. Boreas 22, 299-310.

Seidenkrantz, M.-S., Kristensen, P. \& Knudsen, K. L. 1995: Marine evidence for climatic instability during the last interglacial in shelf records from northwest Europe. Journal of Quaternary Science 10, 77-82.

Sejrup, H. P., Haflidason, H., Kristensen, D. K. \& Johnsen, S. J. in press: Last interglacial and Holocene climatic development in the Norwegian Sea region: Oceanic front movements and ice core data. Journal of Quaternary Science.

Sejrup, H. P. \& Larsen, E. 1991: Eemian-Early Weichselian N-S temperature gradients; North Atlantic-NW Europe. Quaternary International 10-12, 161-166.

Svansson, A. 1975: Physical and chemical oceanography of the Skagerrak and the Kattegat, I, Open sea conditions. Fishery Board of Sweden, Institute of Marine Research, Report No. 1, 1-88.

Thorsen, G. 1995a: The Skaw Spit - a question of settlements. Proceedings XI ECSMFE, DGF-Bulletin 11 (3), 263-268.

Thorsen, G. 1995b: Preconsolidation pressure and creep settlements - Estimations based on results of oedometer tests. In Yoshikuni, H. \& Kusakabe, O. (eds) Compression and Consolidation of Clayey Soils. Proceedings of the International Symposium on Compression and Consolidation of Clayey Soils - IS-Hiroshima'95/Japan. A.A. Balkema/Rotterdam/Brookfield, 287-292.

Thorsen, G. \& Mortensen, P. K. 1995: CPT-investigations in young sediments in the northern part of Jutland. Svenska Geotekniska Föreningen Report 3:95. International Symposium on Cone Penetration Testing, Linköping, Sweden, October 4-5, 1995, Volume 2, Technical Papers, 317-322.

Thouveny, N., de Beaulieu, J.-L., Bonifay, E., Creer, K. M., Guiot, J., Icole, M., Johnsen, S., Jouzel, J., Reille, M., Williams, T. \& Williamson, D. 1994: Climate variations in Europe over the past $140 \mathrm{kyr}$ deduced from rock magnetism. Nature 317, 503-506.

Tzedakis, P. C., Benneth, K. D. \& Magri, D. 1994: Climate and the pollen record. Nature 370, 513 .

Weaver, A. J. \& Hughes, T. M. C. 1994: Rapid interglacial climate fluctuation driven by North Atlantic ocean circulation. Nature 367, 447-450.

Winn, K., Averdiek, F.-R., Erlenkeuser, H. \& Werner, H. 1986: Holocene sea level rise in the western Baltic and the question of isostatic subsidence. Meyniana 38, 6180 . 